\title{
Trade Liberalization and Productivity Growth: Evidence from Indian Manufacturing
}

\author{
Satish Chand ${ }^{1}$ and Kunal Sen ${ }^{1,2}$ \\ ${ }^{1}$ Department of Economics and ${ }^{2}$ Australia South Asia Research Centre \\ Research School of Pacific and Asian Studies \\ The Australian National University
}

\begin{abstract}
The impact of trade liberalisation on productivity growth is still an empirical issue; the theoretical literature is as yet unclear on the direction of any such association. This paper develops an analytical framework and employs it to empirically test if trade liberalisation in Indian manufacturing has raised total factor productivity (TFP) growth. The answer is in the affirmative. Our results also support a key postulate of the new growth theories that liberalisation of the intermediate good sectors has a larger favourable impact on TFP growth than that of the final good sectors.
\end{abstract}

JEL Classification: F14, D24, O53. 


\section{Trade Liberalization and Productivity Growth: Evidence from Indian Manufacturing*}

\section{Introduction}

The impact of trade liberalization on productivity growth in the manufacturing sectors of developing countries remains a controversial issue. The conventional wisdom in favour of trade liberalization is that the latter can lead to significant gains in productivity. This view has, however, been challenged by the new theories of endogenous growth. The new growth theories do allow for the possibility that trade reforms may bring about a permanent change in productivity growth. However, the theoretical literature does not yield an unambiguous prediction on the direction of the change (see the surveys by Rodrik 1988 and 1992, and Tybout 1992). Given this ambiguity, the impact of trade policies on productivity growth is ultimately an empirical question.

However, the available empirical evidence on this issue has been far from conclusive - studies for developing countries that use firm- or industry-level data do not find an unequivocal positive relationship between trade reforms and productivity growth (see surveys by Havrylshyn 1990, Nishimizu and Page 1990 and Rodrik 1995). Moreover, most of these studies have been plagued by both conceptual and empirical shortcomings. Firstly, the studies rarely pay attention to the explicit theoretical mechanisms through which trade policy may impact on productivity growth. As Rodrik (1995) notes, "since the conceptual issues are rarely sorted out as a prelude to empirical analysis, the hypothesized cause-and-effect are difficult to interpret" (p. 2935). Here we explore the relationship between trade policy and productivity growth by identifying and testing two mechanisms by which trade policy may impact on total factor productivity growth. The first is the standard $\mathrm{X}$-inefficiency argument that relate import competition to work effort on the part of workers. The second is trade acting as a conduit for access to specialised inputs, including capital, for production.

\footnotetext{
* Acknowledgements: We would like to thank Sudipta Dutta Roy and Rajendra Vaidya for assistance in data compilation and participants at the RSPAS Economics Department seminar for comments. The usual disclaimer applies.
} 
A second limitation of this literature is empirical in that there has been lack of reliable measures of trade policy changes (Edwards 1993). In earlier studies that have investigated the link between trade liberalization and total factor productivity growth (such as Krueger and Tuncer 1982), causality was attributed merely by association - if there was evidence that total factor productivity increased in the post-reform period, then it must be due to the reforms. More sophisticated analyses in the same vein that have used dummy variables to demarcate the post-reform period from the pre-reform one (such as Ahluwalia 1991and Harrison 1994) are open to the same criticism. More importantly, the use of dummy variables to measure trade reforms implicitly assumes a) that the trade reform was an once and for all event, and b) that it was complete. Neither of these two conditions may be satisfied in most trade liberalization episodes that one observes in developing countries ( see the survey of recent trade liberalization episodes by Michaely et al. 1991) The usefulness of dummy variables to capture trade policy shifts is greatly diminished if the trade liberalization has been gradual over time or if the reforms have been proceeding at an uneven pace across sectors.

Other measures of trade policy that are common in the empirical literature are import penetration ratios and effective rates of protection The former is problematic for two reasons. Firstly, it measures the outcome of changes in trade policies rather than the policies themselves. Secondly, significant trade reforms may affect productivity growth without being reflected in import volumes. On the other hand, while the effective rate of protection is a more direct measure of trade policy, its usefulness in empirical work is hindered by the unavailability of enough observations over time to undertake any meaningful econometric analysis. Clearly then, a pre-requisite for further empirical analysis on the relationship between trade policy and productivity changes at either the firm or industry level is to obtain a measure of 'protection' that is sufficiently detailed both from a time-series and cross-sectional perspective so that it captures differences in the degree of reforms across industries and the degree of variation in the reforms themselves over time. This paper uses a measure of protection that is less susceptible to 
the criticisms made of other measures and is also sufficiently informative in that it can capture changes in trade policy both across industries and over time. This measure is based on a comparision of the domestic and international price of a particular industry the price wedge.

The paper studies the effect of trade liberalization on the total factor productivity growth in Indian manufacturing using panel data on 30 industries over 1973-88. A casestudy of Indian manufacturing is particularly relevant for the issues at hand for two reasons. Firstly, a unique feature of trade reforms in India during this period has been that it has almost exclusively focused on the intermediate and capital goods sectors with little change in import controls on consumer goods imports. This enables us to test the role of intermediate-goods liberalisation on productivity growth. Secondly, during this period, the Indian economy has witnessed a slow but steady liberalization of the trade regime pertaining to the manufacturing sector. This liberalization has by no means been complete and its progress has differed widely across different industrial sectors. Therefore, the Indian trade liberalization of the 1970s and 1980s does not lend itself to a straightforward before-after analysis.

The rest of the paper is structured as follows. In Section 2, we provide a brief overview of Indian trade policies in the 1970s and 1980s. In Section 3, we quantify the extent of protection in Indian industry using our preferred measure, the price wedge. Section 4 presents the analytical framework and Section 5 the empirical analysis. Section 6 concludes. A data appendix discusses the choice of industries and the period of our analysis, the sources of the data and the method of construction of the variables used in the regression analysis. 


\section{Trade Policy in India ${ }^{1}$}

In the beginning of the 1970s, India had a highly restrictive trade regime. Nearly all imports were subject to discretionary import licensing or were "canalized" by government monopoly trading organizations. The only exceptions were commodities listed in the Open General License (OGL) category. Capital goods were divided into a restricted category and the OGL category. While import licenses were required for restricted capital goods, those in the OGL could be imported without a license subject to several conditions. The most important of these were that the importing firm had to be the "actual user" of the equipment and could not sell the latter for five years without the permission of the licensing authorities and that the resulting change in capacity must be compatible with the capacity approved by the industrial licensing authorities. Intermediate goods were divided into the banned, restricted and limited permissible categories plus an OGL category. As these names suggest, the first three lists were in order of import licensing stringency. OGL imports of intermediate goods were also governed by the "actual user" condition. The import of consumer goods were, however, banned (except those which were considered "essential" and could only be imported by the designated government canalizing agencies).

Beginning with the export-import policy of 1977-78, there was a slow but sustained relaxations of import controls. Several capital goods that were not allowed to be imported without an import license were steadily shifted to the OGL category. The number of capital goods on the OGL list increased from 79 in 1976 to 1170 in April 1988. These changes were made with the intention of allowing domestic industries to modernize and OGL status was usually accompanied by reduced customs tariff rates. Moreover, during the 1980s the import licensing of capital goods in the restricted list were administered with less stringency (Pursell 1992). As a consequence, the import penetration ratio in the capital goods sector increased from 11 per cent in 1976-77 to 18 per cent in 1985-86 (Goldar and Renganathan 1990). In the case of intermediate goods

\footnotetext{
${ }^{1}$ The discussion in this section is confined to the trade regime of the 1970s and 1980s and draws heavily from The World Bank (1989), Aksoy (1992) and Pursell (1992). For discussions of the pre-1970 period, see Bhagwati and Desai (1970) and Bhagwati and Srinivasan (1975).
} 
too, there was a steady shift of items from the restricted and limited permissible categories to the OGL category. However, in the case of both capital and intermediate goods, in most cases these goods were placed in the OGL list if they were not being domestically produced. Thus, import liberalization during this period may not have led to immediate direct competition to established producers of intermediate and capital goods in India (though in several instances, the goods that were allowed to be imported were imperfect substitutes of domestically produced goods). Furthermore, the average effective tariff rate for capital goods increased from 37 per cent in 1973-74 to 63 per cent in 198889. Also, consumer goods remained in the banned list for the entire duration of the 1970s and 1980s.

The pace of the trade reforms - in particular, the shift from quantitative import controls to a protective system based on tariffs - initiated in the mid-seventies were considerably quickened by the new government (led by Rajiv Gandhi) that came into power in November 1985. Also, beginning in the mid-eighties, there was a renewed emphasis by the new administration on export promotion. The number and value of incentives offered to exporters were increased and their administration streamlined. The allotment of REP licenses - tradeable import entitlements awarded to exporters on a product-specific basis - became increasingly generous (Agrawal et al. 1995). At the same time, the exchange rate became an important tool of export promotion and there was a steady devaluation of the Indian rupee during this period (Figure 1). The latter may have counteracted the decrease in protection brought about by the liberalization of import controls in the Indian manufacturing sector.

To sum up, trade liberalization in India during the 1970s and 1980s was far from being comprehensive in its coverage or complete in its implementation. Yet the trade regime of the late eighties was considerably more liberal than that of the early seventies. The question we would like to ask then is: did these reforms in trade policy have any effect on total factor productivity growth of the Indian manufacturing sector during this period? 


\section{Quantifying Protection}

The measure of protection that we use is the "price wedge" - the deviation of the domestic price of the output produced by a particular industry from the world free trade price for that industry. Protection impinges on productivity growth via the degree of slack that it provides to domestic producers relative to their international competitors, and any such slack would be reflected as a positive deviation of the domestic price from the international price. $^{2}$

We approximate the world free trade price of a particular industry by the price prevailing in the United States for that industry. Thus, we define the protection rate, $\mathrm{R}_{\mathrm{it}}$, for industry $i$ at time $t$ as:

$$
\mathrm{R}_{\mathrm{it}}=\frac{\mathrm{P}_{\mathrm{it}}^{\text {INDIA }}}{\mathrm{P}_{\mathrm{it}}^{\text {USA }} * \mathrm{e}_{\mathrm{t}}},
$$

where $\mathrm{P}_{\mathrm{it}}^{\mathrm{INDIA}}$ and $\mathrm{P}_{\mathrm{it}}^{\mathrm{USA}}$ are the implicit price deflators of industry $\mathrm{i}$ at time $\mathrm{t}$ for India and the United States respectively and $e_{t}$ is the exchange rate (Indian rupees per US dollar). The implicit price deflators, $\mathrm{P}_{\mathrm{it}}^{\mathrm{INDIA}}$ and $\mathrm{P}_{\mathrm{it}}^{\mathrm{USA}}$, for a particular industry are obtained by deflating the industry's value of production by the relevant quantity index. We adjust $\mathrm{R}$ for differences in the quality of the product across the two countries using price parity ratios (for the year 1980) obtained from the International Comparision Project (UN 1987). According to our measure, protection increases in a particular industry in India if its domestic price increases relative to that of the US or if the nominal exchange rate depreciates.

The ability of the measure to reveal the "true level of protection" in a particular industry depends critically on the level of disaggregation at which the price indices are

\footnotetext{
${ }^{2}$ As Harrison (1996, p. 421) observes, "price comparisions between goods sold in domestic and international markets could provide an ideal measure of the impact of trade policy".
} 
computed. This is for two reasons. Firstly, the "price wedge" as a measure of protection is feasible only for products in which the quality adjustments are not overwhelming and where the products compared are fairly homogenous in terms of their characteristics (Pritchett 1996). The greater the level of disaggregation, the more similar is the industry's product between the two countries. Secondly, in a highly complex trade regime as was the case in India, changes in trade policy have differed widely across industries. Aggregating over industries with disparate levels of protection can lead to a significant loss in the information content of our measure. ${ }^{3}$

We confine our analysis to 30 industries over the time-period 1973-88. Both the choice of industries and time-period are dictated by data considerations. A detailed explanation on the choice of industries and time-period along with the method of construction of the variables used in the empirical analysis is provided in a data appendix. The list of industries is provided in Table 1 along with the 3 digit National Industries Classification Code (NIC), which is the classification code used by the Central Statistical Organisation (CSO), the agency responsible for the preparation of the data on industries in India. The level of disaggregation of the industries at the NIC 3 digit level coincides with that of the ISIC 4 digit level and is the maximum level of disaggregation that the data will permit. Given that these 30 industries were "chosen" out of a possible 166, the possibility of a selection bias in the empirical analysis that follows cannot be discounted. Note, however, that these industries accounted for 53 per cent of gross value added and 45 per cent of total employment in the Indian manufacturing sector for the period 197388. Note also that the 30 industries are divided in roughly equal proportion across the three major industry groups - consumer goods, intermediate goods and capital goods.

\footnotetext{
3 To take two examples, consider the 3 digit ISIC industries - Electrical Machinery (383) and Transport Equipment (384). In the first case, audio and video equipment (ISIC 3832) - a consumer goods industry - is clubbed together with several capital goods industries, such as electrical industrial machinery (ISIC 3831) and insulated wires and cables (ISIC 3839). Similarly, in the second case, another consumer goods industry, motor vehicles (ISIC 3843), is clubbed together with other capital goods industries, e;g., railroad equipment (ISIC 3842). As we have already noted, Indian trade policy with respect to capital goods has differed significantly from that with respect to consumer goods.
} 
In Figure 2 to 9, we present time-plots of our measure of protection for the 30 industries in our sample. Since both the level and the change in protection has differed across the three industry groups - consumer goods, intermediate goods and capital goodsover the period 1973-88, the time-plots of protection are presented in three sets, each corresponding to an industry group. The figures indicate that, on average, protection has remained the same or marginally decreased in the case of industries in the consumer goods sector. However, there is a perceptible decrease in protection for the intermediate goods sector (with the exception of cotton ginning, and tyres \& tubes) particularly since the early eighties. A similar pattern can be observed in the case of industries in the capital goods sector (except insulated wires and cables, and railroad equipment).

The behaviour of $\mathrm{R}$, the price wedge, in most of the 30 industries of our sample are in accord with our prior belief that the trade liberalization initiated in the Indian economy in the mid-seventies has brought about a decrease in protection in the intermediate and capital goods sectors but not so in the consumer goods sector. The ability of $\mathrm{R}$ to capture changes in trade policy pertaining to the Indian manufacturing sector both across industries and over time provide some support for the use of the price wedge as an indirect measure of trade policy in the empirical analysis of Section 5.

\section{The Analytical Framework}

The mechanics linking trade and productivity is as yet an open question in the theoretical literature, as noted previously. Here we employ two channels via which trade liberalisation impinges on TFP growth. The first relies on the X-inefficiency literature where trade reform leading to increased international competition brings about a reduction in "slack" in labour input (see Horn, Lang, and Lundgren 1996; Vousden 1995). The second channel via which trade reform raises productivity uses the "love of variety" formulation of Dixit and Stiglitz (1977) where access to a greater variety of specialised inputs raises TFP growth when these inputs are imperfect substitutes for one another (Romer 1987). The above two mechanisms are incorporated within the standard 
neoclassical production function to deduce a reduced form that gives trade liberalisation a role in growth.

Let the sectoral production function be of the form

$$
Y=A(t) F\left(K^{*}, L^{*}\right)
$$

where $\mathrm{Y}$ is output, $\mathrm{A}$ an index of Hicks neutral technological progress, $\mathrm{K}$ is stock of physical capital and $\mathrm{L}$ is labour input with superscript $*$ denoting the effective quantity of the factors used in production. We observe $\mathrm{Y}, \mathrm{K}$ and $\mathrm{L}$ where

$$
K^{*}=U(R, t) K
$$

and

$$
L^{*}=E(R) L
$$

$\mathrm{U}$ is the utilisation rate of capital, and $\mathrm{E}$ is an index for the quantity of effort put in by labour. $\mathrm{R}$ could be a vector comprising a host of variables that determine the level of effort put in by workers and the utilisation rate of capital, but here we will confine ourselves to consider the role of trade only. Differentiating (1) after substituting in (2a) and (2b) gives

$$
\hat{Y}=\hat{A}+s_{K}(\hat{K}+\hat{U})+s_{L} \hat{L}-\beta_{1} \hat{R}
$$

where a carat over a variable denotes proportional change. If the production function in (1) is linearly homogeneous then $s_{K}$ and $s_{L}$ denote factor shares, the sum of which should equal one. 
Access to specialised inputs is another channel via which trade liberalisation can impinge on TFP growth. The role of intermediate inputs in productivity growth can be significant via two channels. First, if the production function takes the form

$$
Q=F(K, L, M)
$$

where $\mathrm{Q}$ is output gross of material inputs, $\mathrm{M}$, which in turn is a composite of imperfect substitutes, $m$ of type $j$;

$$
M=\left[\sum_{j=0}^{\infty} \alpha_{j} m(j)\right]^{\frac{1}{\rho}}, \sum_{j} \alpha_{j}=1
$$

where the elasticity of substitution between the individual inputs types is given by $\frac{1}{1-\rho}$. Now, an increase in access to differentiated inputs is also going to bring about a rise in TFP. Alternatively, we could think of $K$ in equation (1) as an aggregate,

$$
K=\left[\sum_{j=0}^{\infty} \gamma_{j} k(j)\right]^{\frac{1}{\rho}}, \sum_{j} \gamma_{j}=1
$$

where $j$ could for example be an index of the specificity and/or vintage of a particular type of capital. Output in equation (1) rises through gains in access to specialised inputs even when the overall quantity of inputs is held constant (see Grossman and Helpman 1991: Chapter 3). Hence, liberalisation of the intermediate and/or capital goods sector(s) in the above framework leads to gains in TFP. Now incorporating either (4) or (4a) into (3) gives an estimable equation of the form

$$
\hat{Y}=\alpha_{0}+\alpha_{1} \hat{K}+\alpha_{2} \hat{U}+\alpha_{3} \hat{L}-\beta_{1} \hat{R}+\beta_{2} \hat{J}, \alpha, \beta>0
$$


where $\mathbf{J}$ denotes the number of intermediate inputs available at time t, the $\alpha$ s denote technology coefficients, the $\beta$ s measure the responsiveness of output growth to changes in policy-related variables. A constant returns to scale technology would imply that $\alpha_{1}+\alpha_{3}=1$. The literature on trade policy and TFP growth suggests that there are a number of channels via which trade policy can impinge on growth, the robust finding from all these specifications is that the association is negative as implied by (5) above. ${ }^{4}$ Controlling for growth of $\mathrm{K}^{*}$ and $\mathrm{L}^{*}$ in (5) gives an alternate specification of (5) as

$$
T \hat{F P}=\alpha_{0}-\beta_{1} \hat{R}+\beta_{2} \hat{J}
$$

where now TFP may be measured explicitly. The above two equations form the basis of the empirics that follow.

\section{Empirical Analysis}

In Table 2, we present the summary statistics of the key variables used in the regression analysis - $\hat{Y}, \hat{K}, \hat{L}$ and $\hat{R}$. The first column of the table reports the mean and the next two columns decompose the variance of each variable into its between-industry and withinindustry estimates. We adopt the terminology conventionally employed by panel data studies: "between-industry" refers to the differences in industry-specific averages across industries, where the averages are computed over time, and "within-industry" refers to deviations of variables from these industry-specific means. We find that within-industry variation accounts for 90 per cent or more of the total variance of each of the four variables in question. This indicates that studies that use measures of protection that are cross-sectional in nature (such as tariff-based computations of effective rates of protection) to decipher a negative relationship between protection and total factor productivity may not meet with much success in the Indian context.

\footnotetext{
${ }^{4}$ See Levinshon (1993) and Havrylyshyn (1990) for an extensive survey on these issues.
} 
In Table 3, we present estimates of total factor productivity growth using the Tornquist index formula and changes in protection $(\hat{R})$ for the three major industry groups - consumer goods, intermediate groups and capital goods - averaged over three non-overlapping five year periods - 1974-78, 1979-83 and 1984-88. The table clearly indicates a significant improvement in total factor productivity growth across all three industry groups in the period 1984-88 as compared to the two earlier periods. ${ }^{5}$ This seems to have coincided with a significant acceleration in the rate of decrease in protection in the same period, particularly in the intermediate and capital goods sectors.

To test the above observed relationship more rigorously, we estimate equation (5) using panel data for the 30 industries in our sample over the period 1973-88. We employ the fixed-effects estimator to allow for intrinsic differences across industries with respect to the rate of technological progress. We use the standard procedure of sweeping out the fixed effects by transforming variables to deviations from their industry-specific means. An index of capacity utilisation is constructed so as to control for transitory shocks to productivity due to cyclical factors. We assume that the impact of changes in protection on output growth in manufacturing is equal across the component three digit NIC industries. This assumption would be particularly valid in the event of complete factor mobility between these industries. The policy affected variables, $\hat{R}$ and $\hat{J}$, are lagged by one year. This is done for two reasons. Firstly, changes in policy take time to impact on endogenous variables, the one year lag capture the first-order effects which are expected to be most pervasive; and secondly, lagging $\hat{R}$ by one period precludes the possibility of reverse causality - that is, more efficient industries are liberalized earlier or faster. ${ }^{6}$

Model 1 is an estimate of the Solow growth accounting identity, the rest are augmented with the variables as suggested in Section 3 above. Model 2 is an estimate of equation (5). Model 3 uses protection data for the intermediate goods in place of the extent of intra-industry trade measure to check the robustness of the findings in the

\footnotetext{
5 An across-the-board improvement in total factor productivity growth in Indian industries in the mideighties has also been observed by Ahluwalia (1991) and Srivastava (1996).
} 
estimate for Model 2. Model 4 decomposes the changes in protection into its constituent components, the changes in domestic prices, changes in foreign prices and changes in exchange rate.

The adjusted coefficient of variation is low for all the estimates, but is particularly low for Model 1. The low coefficient of variation is not surprising given that estimates are for growth rates, a panel data is used, and fixed effects procedure has been employed which employs dummy variables for each of the industries. We note that use of the OLS procedure gives an adjusted coefficient of variation of approximately twenty percent in the augmented models. If we use Model 1 as the benchmark, then the augmented models are considerably better at explaining the variation in the data. Furthermore, the objective here is to investigate the role of trade liberalisation in TFP growth, hence the ability of the model to explain the variation is not of primary concern.

The estimates of the technology coefficients in the augmented models are more plausible then that in Model 1. The assumption of constant returns to scale is not rejected in any of the augmented models, though the point estimates suggest decreasing returns to scale. All of the $\beta$ coefficients, the coefficient of interest to this study, have signs that are in accord with the theoretical priors. The estimates suggest that a rise in price distortion has a statistically significant negative impact on growth while a rise in extent of intraindustry trade in intermediate goods has a positive impact. ${ }^{7}$ A comparison of the point estimates on $\hat{R}$ in Model 2 with that in Model 3 suggests that liberalisation of the intermediate goods sector has had a larger impact on TFP growth relative to liberalisation of all the sectors.

The point estimates of the individual parameters in the augmented models are statistically indifferent across the three models. The estimates suggest that on average, a one percentage point rise in the price wedge leads to a 0.1 percentage point decline in

\footnotetext{
${ }^{6}$ See Magee (1994) for a recent survey of theories of endogenous protection.
} 
TFP growth. This effect for the intermediate goods sector is approximately double. The source of the negative coefficient on $\hat{R}$ can be deduced by decomposing the variable into its constituent components. Before doing this we test the restrictions, as implied by R, that $\hat{R}=\hat{P}-\hat{P}^{*}-\hat{e}$ where $\mathrm{P}$ and $\mathrm{P}^{*}$ denote domestic and US prices, respectively. This restriction is accepted with a p-value on the F-statistic of 0.66 . The decomposition of $\hat{R}$ (Model 4) suggests that it is the changes in domestic prices, rather than that in foreign prices or the exchange rate, that give rise to the negative and statistically significant coefficient on the protection variable. Since this variable is impacted upon by policy, this provides further support for the view that changes in domestic sectoral policies is the primary determinant of sectoral TFP growth. The point estimate of the responsiveness of TFP growth to changes in $\mathrm{R}$ is not large, but it is the qualitative result that is of significance to the subsequent discussion. The finding that a reduction in the price wedge and the liberalisation of the intermediate good sectors have statistically significant impact on productivity growth is found in all of the estimates.

We examined the robustness of this finding by carrying out three further estimates. Firstly, imposing the statistically acceptable restriction of constant returns to scale on the parameters of $\hat{K}$ and $\hat{L}$, we estimated equation (5a) where a direct measure of TFP growth using the Tornquist index formula is used as the dependent variable (Model 5). We do this to control for the endogeneity of $\hat{K}$ and $\hat{L}$ arising out of their possible correlation with demand shocks included in the error term. Secondly, we used year-specific dummies in place of the industry-specific capacity utilisation indices to incorporate temporary economy-wide shocks to productivity (Model 6). Finally, we use data averaged over three year non-overlapping periods for a second estimate of equation (5) (Model 7). By doing so, we control for the possibility that serially correlated exogenous supply shocks may bring about a spurious negative relationship between changes in domestic prices and productivity growth. By averaging over three years, we should be able to iron out fluctuations in the variables in question arising out of short-run

${ }^{7}$ We also experimented with introducing additional lags of $\hat{R}$ and $\hat{J}$ in Models 2 and 3 with no change in 
shocks to the production function and domestic prices. These results are reported in Table 5. We find that in all three estimates, there is no difference to our qualitative results with the coefficients on the variables of interest retaining their correct signs and statistical significance.

\section{Conclusions}

The question investigated in this paper has been whether trade reform in Indian manufacturing has had a positive impact on TFP growth. The answer is in the affirmative and is robust to three sensitivity tests. The two secondary findings of the paper include the demonstration of a simple method of testing the hypothesis that rise in availability of specialized inputs raises TFP growth and an illustration of use of a price-wedge as an alternative measure of the extent of protection.

The case of Indian manufacturing for the examination of the central hypothesis of this paper is suitable for the following reasons. First, the reform process in India has been gradual, as against being sudden, in that a before-after analysis is not suitable. Second, Indian reform with respect to the final and intermediate goods sectors has been different allowing for the examination of the hypothesis that the liberalisation of the intermediate good sectors is more important than that of the final goods sectors for TFP gains. Third, data on variables of interest has been available (albeit for a limited number of industries) in published form.

The point estimates of labour and capital shares in total output suggest that the industries are not perfectly competitive in that compensation to labour and capital do not exhaust total output. ${ }^{8}$ An alternative (complementary) method of testing the primary hypothesis of this paper is to analyse the impact of trade liberalisation on industry markups. This is an exercise for future research.

\footnotetext{
the qualitative results.

${ }^{8}$ This finding lacks statistical significance as noted in the empirics.
} 


\section{Data Appendix}

Choice of Industries: The choice of the 30 industries were dictated by two considerations: i) Estimation of equations (5) and (5a) require the availability of a satisfactory capital stock series for the period of the study. Aggarwal (1991) has constructed a capital stock series in constant prices for 42 of the largest industries in the Indian manufacturing sector using the Perpetual Inventory Method (PIM). In constructing the series, he has paid careful attention to the estimation of the initial period capital stock (see below); ii) To compute $\mathrm{R}$, a precise mapping from the 3 digit NIC classification system used in preparing industry data in India to the 4 digit ISIC system of the US is necessary. This mapping was possible to implement for 30 of the 42 industries in Aggarwal's study. These were the final set of industries used in our study.

Choice of Period: We were interested in evaluating the impact of trade reforms on TFP growth in India for the seventies and eigthties - a period which witnessed significant changes in Indian trade policy. 1973 was chosen as the starting year of our analysis as there was a change in the classfication and coverage of industries in that year which made industry data from the pre-1973 period non-comparable with later years. We ended in 1988 as there was another change in classification in some of the industries in our sample in the following year.

Rate of Protection $(R)$ : We have defined the rate of protection for industry $\mathrm{i}$ at time $\mathrm{t}$ to be:

$$
\mathrm{R}_{\mathrm{it}}=\frac{\mathrm{P}_{\mathrm{it}}^{\text {INDIA }}}{\mathrm{P}_{\mathrm{it}}^{\text {USA }} * \mathrm{e}_{\mathrm{t}}},
$$

where $\mathrm{P}_{\mathrm{it}}^{\mathrm{INDIA}}$ and $\mathrm{P}_{\mathrm{it}}^{\mathrm{USA}}$ are the implicit price deflators of industry $\mathrm{i}$ at time $\mathrm{t}$ for India and the United States respectively, and $e_{t}$ is the official exchange rate (Indian rupees per US dollar). The price deflators were obtained by deflating values of production at the 4 digit ISIC level by corresponding indices of industrial production. For India, data on the index of industrial production is obtained from the Monthly Abstract of Statistics published by 
the Central Statistical Organisation and for the United States, data is obtained from the Board of Governors of the Federal Reserve. Value of production data for the United States is obtained from the UNIDO's Industrial Statistics data-base. The exchange-rate series has been obtained from the International Financial Statistics published by the International Monetary Fund.

Real Value Added (Y): We obtain real value added using the double-deflation method. Thus, real value added for industry $i$ is defined as:

$Y_{i}=\frac{O_{i}}{P_{i}}-\frac{M_{i}}{P M_{i}}$, where $\mathrm{O}_{\mathrm{i}}$ is Gross Value of Output and $\mathrm{P}_{\mathrm{i}}$ is the product price of the industry, and $\mathrm{M}_{\mathrm{i}}$ is the cost of total inputs and $\mathrm{PM}_{\mathrm{i}}$ is the price of materials for the industry.

The use of the double-deflation method avoids the possible bias to the measurement of real value added emanating from changes in the relative price of inputs (Bruno 1978, 1984). Data on the relative price of inputs for the manufacturing sector as a whole for the period 1973-88 (presented in Balakrishnan and Pushpangadan 1994) indicate significant variation in the latter during this period.

Gross value of output and the cost of total inputs for each industry are obtained from the Annual Survey of Industries (Summary Results on the Factory Sector), published by the Central Statistical Organisation, India. Product prices are obtained from the Index of Wholesale Prices (adjusted for changes in base years), published by the same organisation.

Ideally, $\mathrm{PM}_{\mathrm{i}}$ should be a weighted average of the prices of all inputs used by industry $\mathrm{i}$, the weights being the proportion of each input used in the production of industry i's output. These weights may be obtained from the relevant input-output tables. However, the unavailability of a suitable concordance between the input-output sectors and the industries contained in the Annual Survey of Industries prevented us from 
adopting such a procedure. Instead, we used an aggregate index of materials prices for the manufacturing sector as a whole (computed using weights obtained from the input-output tables of 1973-74) presented in Balakrishnan and Pushpangadan (1994).

Capital Services (K): We assume that services of capital are proportional to its stock. Aggarwal provides estimates of gross capital stock for the 30 industries in our sample for the period 1961-86 using the PIM with 1960 being the bench-mark year for the estimation of fixed capital at replacement cost. We update Aggarwal's estimates for later years. As is well-known, capital stock derivation using the PIM is sensitive to the base-year estimate of capital stock at replacement cost. A strength of Aggarwal's estimates is that they are obtained by using ratios of replacement cost to book value of different components of fixed capital provided in Hashim and Dadi (1973) for most of the industries in our sample. These ratios are obtained from balance-sheet information of 1000 firms covered by the Annual Survey of Industries for the bench-mark year.

Labor $(L)$ : Defined to be all persons engaged in the production process (not including managerial and supervisory staff) for the particular industry. Data on $\mathrm{L}$ is obtained from the Annual Survey of Industries.

Intermediate goods trade $(J)$ : As is traditional in this literature, the Grubel-Lloyd (1975) index of intra-industry trade has been used to proxy for extent of trade in intermediate inputs (see Backus, Kehoe and Kehoe 1992).

Capacity Utilization $(U)$ : Defined as the deviation of sectoral output from a trend fitted output.

Intermediate Goods Protection ( $R$ intermediates): Is the rate of protection $(\mathrm{R})$ for intermediate goods as categorised in Table 1. 


\begin{tabular}{|c|c|}
\hline $\begin{array}{l}\text { Industry Classification and NIC } \\
\text { Code }\end{array}$ & Industry Name \\
\hline \multicolumn{2}{|l|}{ Consumer Goods } \\
\hline 201 & Dairy Products \\
\hline 204 & Grain Milling \\
\hline 206 & Sugar Refining \\
\hline 210 & Hydrogenated Oils \\
\hline 231 & Cotton Spinning and Weaving \\
\hline 264 & Textile Garments \\
\hline 280 & Pulp, Paper and Paper Board \\
\hline 313 & Drugs and Medicines \\
\hline 314 & Perfumes and Cosmetics \\
\hline 363 & Electric Lamps \\
\hline 364 & Audio and video equipment \\
\hline 374 & Motor Vehicles \\
\hline \multicolumn{2}{|l|}{ Intermediate Goods } \\
\hline 230 & Cotton Ginning \\
\hline 290 & Tanning of Leather \\
\hline 300 & Tyre and Tube Industries \\
\hline 310 & Industrial Organic and Inorganic Chemicals \\
\hline 311 & Fertilizers and Pesticides \\
\hline 312 & Paints and Varnishes \\
\hline 316 & Turpentine, Synthetic Resin, etc. \\
\hline 324 & Cement, Lime and Plaster \\
\hline 330 & Iron and Steel \\
\hline 331 & Foundries for casting Iron and Steel \\
\hline \multicolumn{2}{|l|}{ Capital Goods } \\
\hline 343 & Hand Tools \\
\hline 350 & Agricultural Machinery \\
\hline 352 & Prime Movers, Boilers, etc. \\
\hline 353 & Industrial Machinery for Food \& Textile Industries \\
\hline 356 & General Purpose Non-electrical Machinery \\
\hline 360 & Electrical Industrial Machinery \\
\hline 361 & Insulated Wires and Cables \\
\hline 372 & Railroad Equipment \\
\hline
\end{tabular}


Table 2 Summary Statistics

\begin{tabular}{cccc}
\hline Variables & Mean & \multicolumn{2}{c}{ Variance } \\
\cline { 2 - 4 }$\hat{Y}$ & 0.062 & 1.14 & 8.89 \\
$\hat{K}$ & 0.068 & 0.19 & 1.87 \\
$\hat{L}$ & 0.024 & 0.28 & 5.23 \\
$\hat{R}$ & -0.004 & 1.14 & 16.14 \\
\hline
\end{tabular}

Table 3 Changes in Protection $(\hat{R})$ and Total Factor Productivity Growth (TFPG) by Industry Classification $^{a}$

\begin{tabular}{lrrr}
\hline Industry Classification & $\begin{array}{r}\text { Consumer } \\
\text { Goods }\end{array}$ & $\begin{array}{r}\text { Intermediate } \\
\text { Goods }\end{array}$ & $\begin{array}{r}\text { Capital } \\
\text { Goods }\end{array}$ \\
\hline$\hat{R}$ (percent) & & & -1.8 \\
$1974-78$ & 4.5 & 0.4 & 1.7 \\
$1979-83$ & -1.1 & 1.4 & -4.3 \\
$1984-88$ & -0.4 & -5.4 & \\
TFPG (percent) & & & -1.6 \\
$1974-78$ & -0.5 & -1.2 & -1.5 \\
$1979-83$ & -1.2 & -3.1 & 3.7 \\
$1984-88$ & 5.1 & 4.8 & \\
\hline
\end{tabular}

Note: a. Unweighted Averages. 
Table 4 Regression Estimates employing the Fixed-Effects Procedure

\begin{tabular}{lllll}
\hline Variable & Model 1 & Model 2 & Model 3 & Model 4 \\
\hline$\hat{K}$ & 0.17 & 0.30 & 0.25 & 0.31 \\
& $(1.52)$ & $(2.72)$ & $(2.27)$ & $(2.74)$ \\
$\hat{L}$ & 0.41 & 0.36 & 0.40 & 0.37 \\
& $(6.03)$ & $(5.51)$ & $(6.02)$ & $(5.37)$ \\
$\hat{U}$ & & 0.12 & 0.11 & 0.12 \\
& & $(4.78)$ & $(4.48)$ & $(4.85)$ \\
$\hat{J}_{\mathrm{t}-1}$ & & 0.14 & & 0.14 \\
$\hat{R}_{\mathrm{t}-1}$ & & $(2.16)$ & & $(2.01)$ \\
$\hat{R}_{\mathrm{t}-1}$ (Intermediates) & & -0.12 & & \\
$\hat{P}_{\mathrm{t}-1}$ & & & -0.21 & \\
$\hat{P}^{*}{ }_{\mathrm{t}-1}$ & & & $(-2.76)$ & \\
$\hat{e}_{\mathrm{t}-1}$ & & & & -0.14 \\
& & & & $(-3.58)$ \\
Adj. $\mathrm{R}^{2}$ & & & & 0.066 \\
SER & & & & $(1.03)$ \\
$\#$ obs. & 0.036 & 0.11 & 0.10 & $(0.95)$ \\
\# industries & 0.0603 & 0.0577 & 0.0584 & 0.11 \\
\hline & 420 & 420 & 420 & 420 \\
\hline
\end{tabular}


Table 5 Robustness Tests

\begin{tabular}{lcll}
\hline Variable & Model 5 & Model 6 & Model 7 \\
\hline$\hat{K}$ & - & 0.43 & 0.53 \\
& & $(3.34)$ & $(2.49)$ \\
$\hat{L}$ & - & 0.36 & 0.18 \\
$\hat{U}$ & & $(5.02)$ & $(1.38)$ \\
& 30.65 & - & - \\
$\hat{J}_{\mathrm{t}-1}$ & $(5.50)$ & & \\
& 41.98 & - & 0.52 \\
$\hat{R}_{\mathrm{t}-1}$ & $(2.80)$ & & $(1.51)$ \\
$\hat{P}_{\mathrm{t}-1}$ & & & -0.13 \\
& -43.48 & -0.097 & $(-2.11)$ \\
$\hat{P}^{*} *_{\mathrm{t}-1}$ & $(-4.91)$ & $(-2.22)$ & \\
$\hat{e}_{\mathrm{t}-1}$ & 14.48 & 0.082 & \\
& $(1.00)$ & $(1.17)$ & \\
& 9.20 & 0.91 & \\
& $(0.32)$ & $(0.21)$ &
\end{tabular}

$\begin{array}{llll}\text { Adj. } \mathrm{R}^{2} & 0.05 & 0.09 & 0.01 \\ \text { SER } & 13.26 & 0.0586 & 0.0258 \\ \text { \# obs. } & 420 & 420 & 120 \\ \text { \# industries } & 30 & 30 & 30\end{array}$

Notes: Model 5 has TFPG as dependent variable; Model 6 uses year dummies in place of capacity utilization indices; and Model 7 uses data averaged over three-year nonoverlapping periods. 
Figure 1

The Nominal Exchange Rate

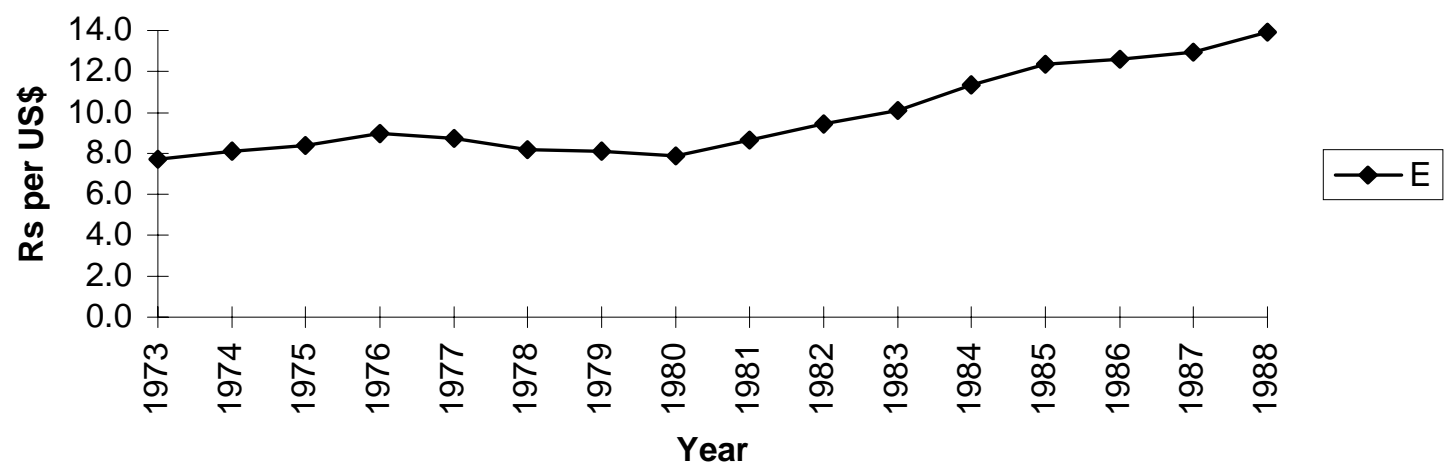

Figure 2

Time-Plot of Protection

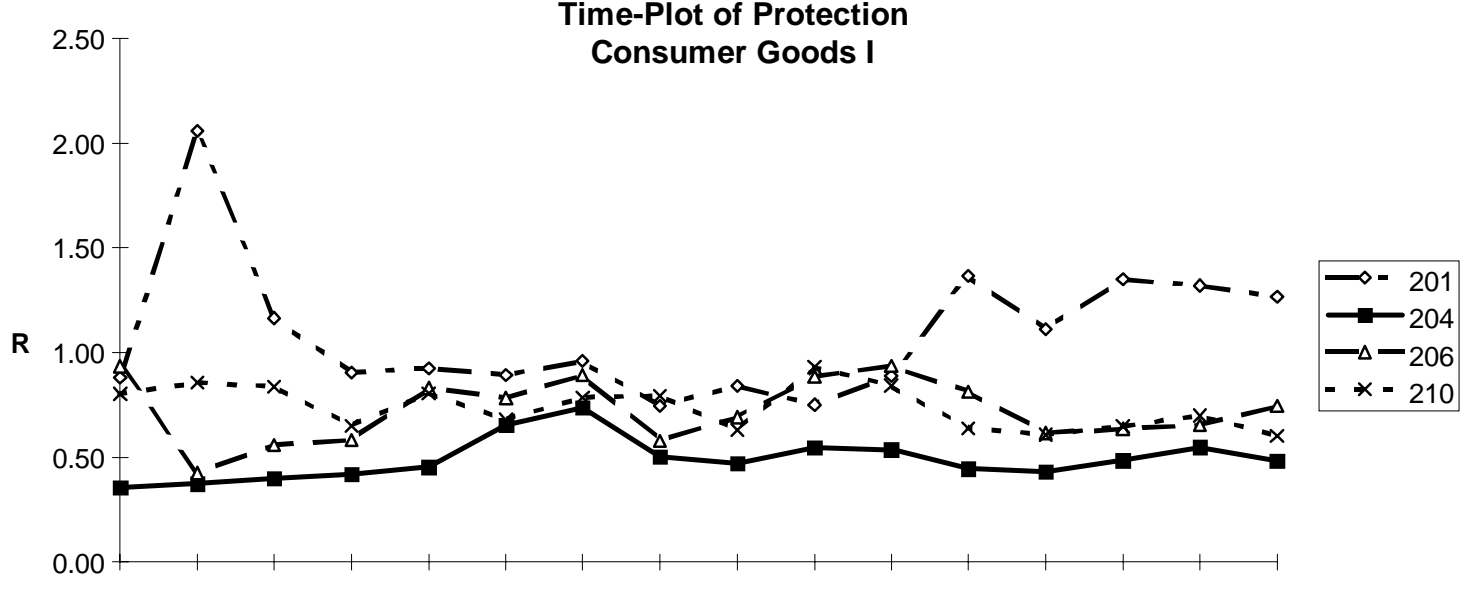

1973197419751976197719781979198019811982198319841985198619871988

$$
\text { Year }
$$


Figure 3

Time-Plot of Protection

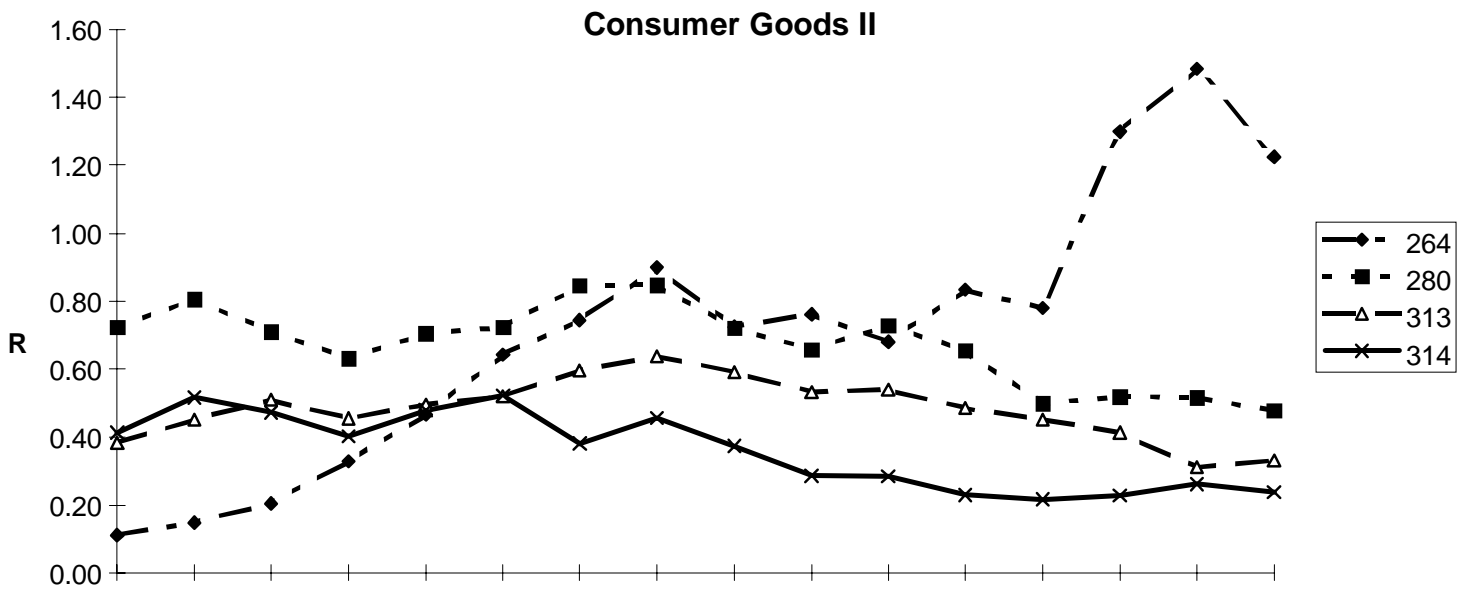

1973197419751976197719781979198019811982198319841985198619871988

Year

Figure 4

Time-Plot of Protection

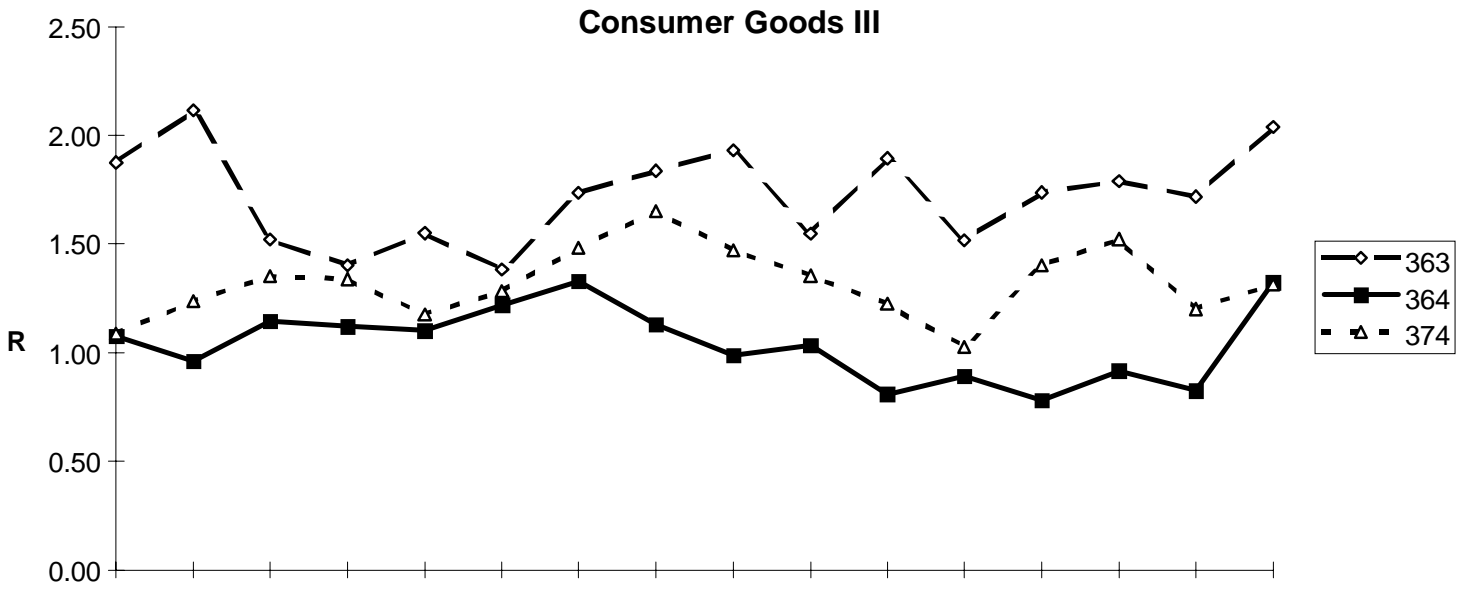

$\begin{array}{llllllllllllllll}1973 & 1974 & 1975 & 1976 & 1977 & 1978 & 1979 & 1980 & 1981 & 1982 & 1983 & 1984 & 1985 & 1986 & 1987 & 1988\end{array}$ Year 
Figure 5

Time-plot of Protection

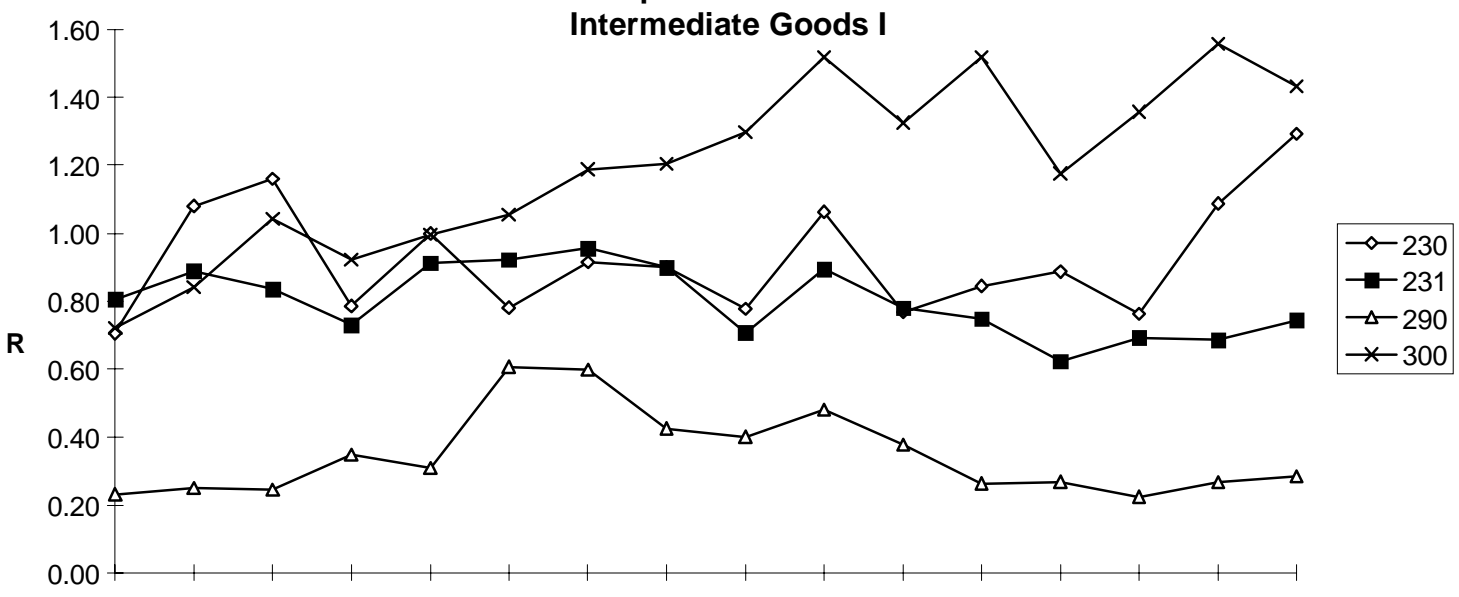

$\begin{array}{llllllllllllllll}1973 & 1974 & 1975 & 1976 & 1977 & 1978 & 1979 & 1980 & 1981 & 1982 & 1983 & 1984 & 1985 & 1986 & 1987 & 1988\end{array}$

Year

Figure 6

Time-plot of Protection

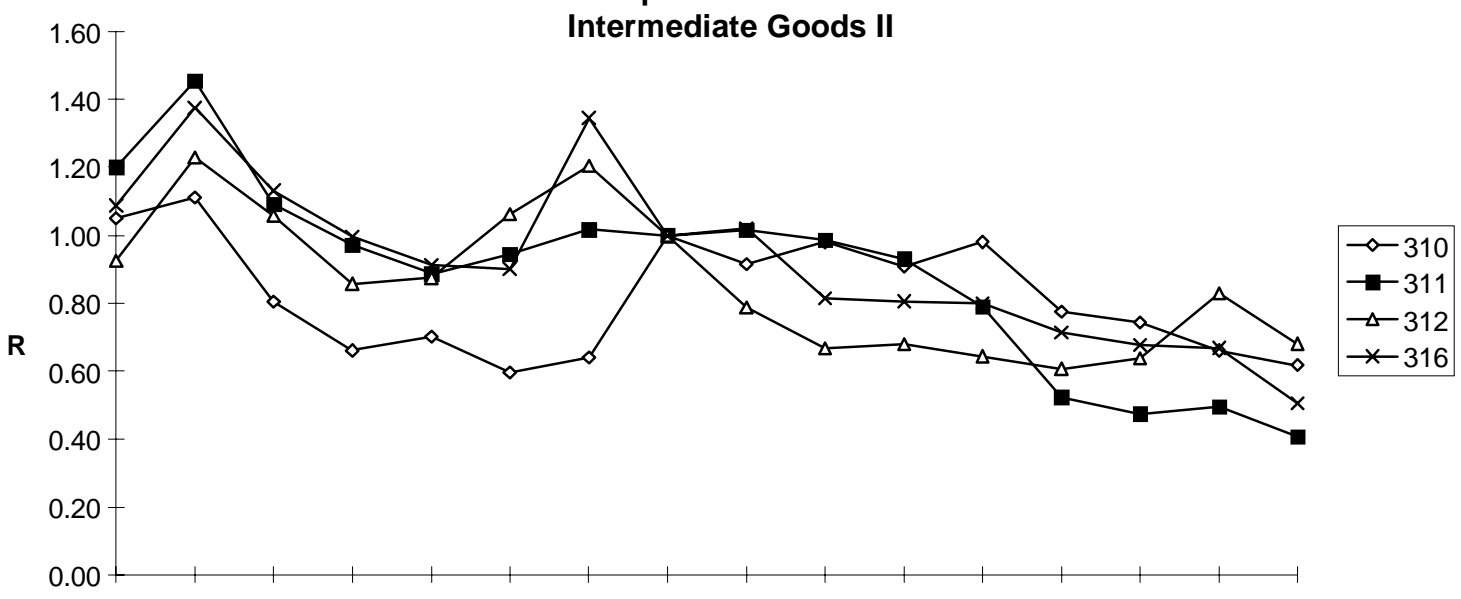

$\begin{array}{llllllllllllllll}1973 & 1974 & 1975 & 1976 & 1977 & 1978 & 1979 & 1980 & 1981 & 1982 & 1983 & 1984 & 1985 & 1986 & 1987 & 1988\end{array}$ Year 
Figure 7

Time-plot of Protection

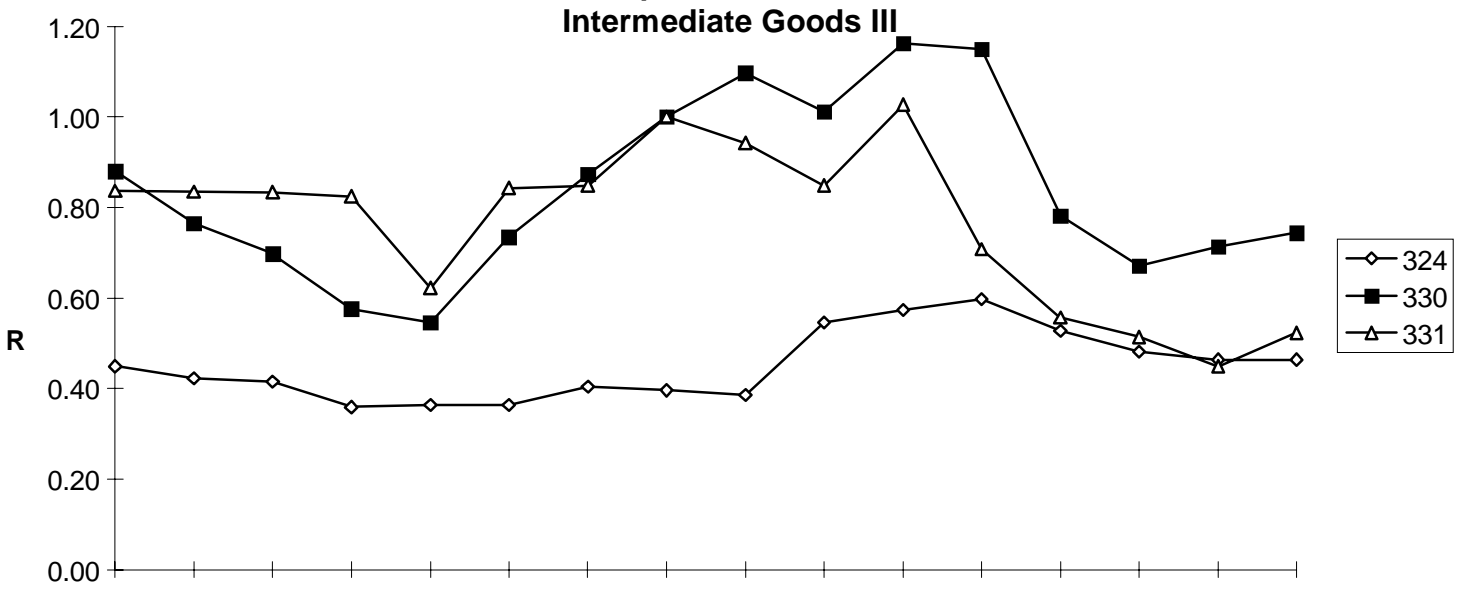

$\begin{array}{llllllllllllllll}1973 & 1974 & 1975 & 1976 & 1977 & 1978 & 1979 & 1980 & 1981 & 1982 & 1983 & 1984 & 1985 & 1986 & 1987 & 1988\end{array}$

Year

Figure 8

Time-plot of Protection

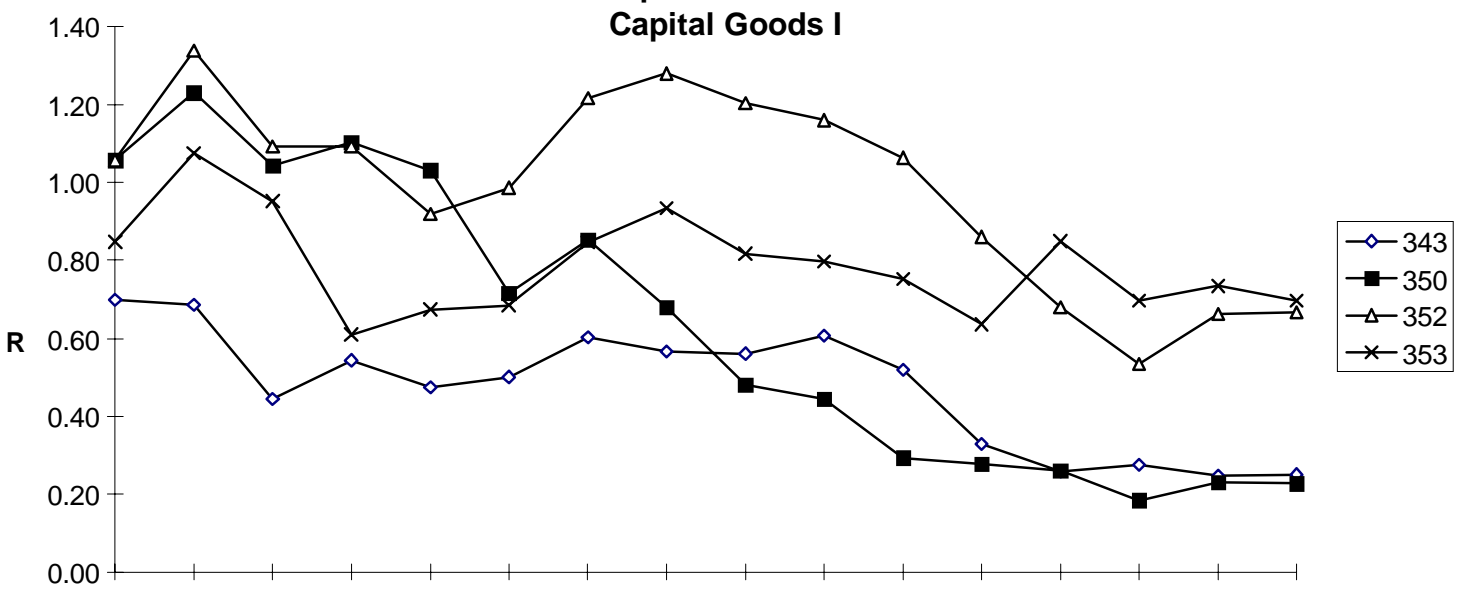

$\begin{array}{llllllllllllllll}1973 & 1974 & 1975 & 1976 & 1977 & 1978 & 1979 & 1980 & 1981 & 1982 & 1983 & 1984 & 1985 & 1986 & 1987 & 1988\end{array}$ Year 
Figure 9

Time-plot of Protection

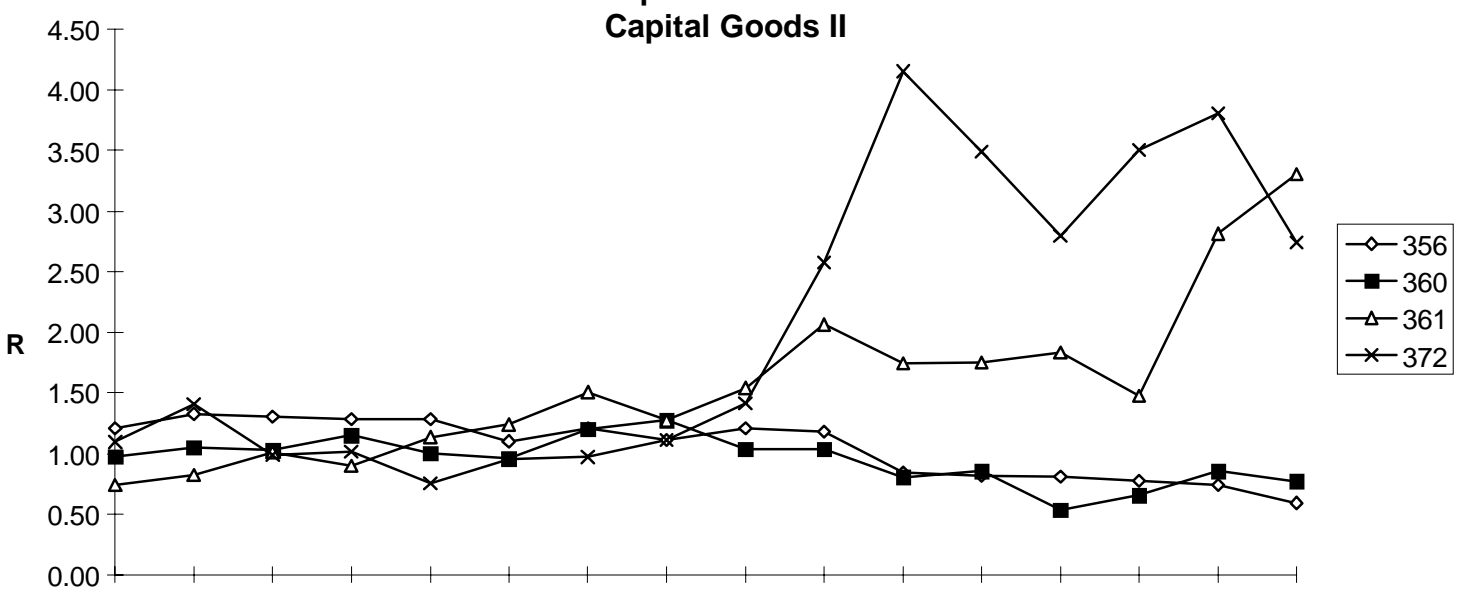

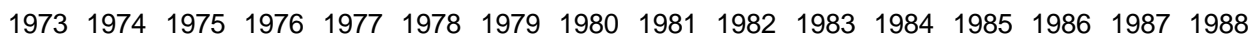
Year 


\section{References}

Agarwal, P.; S Gokarn; V Mishra; K S Parikh and K Sen (1995), Economic Restructuring in East Asia and India: Perspectives on Policy Reform, Macmillan, Basingstoke.

Aggarwal, A K (1991), Estimates of Fixed Capital Stock in Registered Manufacturing Sector in India, Working Paper No. 937, Indian Institute of Management, Ahmedabad.

Ahluwalia I J (1991), Industrial Growth in India, Oxford University Press, New Delhi.

Aksoy, M A (1992), The Indian Trade Regime, WPS 989, The World Bank, Washington D.C.

Backus, D T; P J Kehoe and T J Kehoe (1992), "In Search of Scale Effects in Trade and Growth", Journal of Economic Theory, 58: 377-409.

Balakrishnan P and K Pushpangadan (1994), “Total Factor Productivity Growth in Manufacturing Industry: A Fresh Look”, Economic and Political Weekly, July 30 1994: 2028-35.

Bhagwati, J and P Desai (1970), India: Planning for Industrialization, Oxford University Press, London.

--- and T N Srinivasan (1975), Foreign Trade Regimes and Economic Development: India, Columbia University Press, New York.

Bruno, M (1978), "Duality, Intermediate Inputs and Value Added", Production Economics: A Dual Approach to Theory and Applications, North Holland, Amsterdam.

----(1984), “Raw Materials, Profits and the Productivity Slowdown”, Quarterly Journal of Economics, 1: 1-29. 
Dixit, A and J E Stiglitz (1977), "Monopolistic competition and optimum product diversity", American Economic Review, 67: 297-308.

Edwards, S (1993), "Openness, Trade Liberalization and Growth in Developing Countries", Journal of Economic Literature, 31: 1358-93.

Goldar B and V S Renganathan (1990), Liberalisation of Capital Goods Imports in India, Working Paper No. 8, National Institute of Public Finance and Policy, New Delhi. Grossman, G and E Helpman 1991. Innovation and growth in the Global Economy, MIT. Grubel, H and P J Lloyd (1975), Intra-Industry Trade, Macmillan, London.

Hashim S R and M M Dadi (1973), Capital output relations in Indian manufacturing 1946-1964, M S University Economic Series, Baroda.

Havrylyshyn, O (1990), “Trade policy and productivity gains in developing countries: A survey of the literature", World bank Research Observer, 5(1): 1-24.

Harrison, A E (1994), "Productivity, imperfect information and trade reform: Theory and evidence", Journal of International Economics, 36: 53-73.

----(1996), “Openness and growth: A time-series, cross-country analysis for developing countries", Journal of Development Economics, 48: 419-447.

Horn, H; H Lang and S Lundgren (1996), "Managerial effort incentives, X-inefficiency and international trade”, European Economic Review, 39(1): 117-38.

Islam, N (1995), "Growth empirics: A panel data approach", Quarterly Journal of Economics, 110(4): 1127-70.

Krueger, A O and B Tuncer (1982), "Growth of factor productivity in Turkish manufacturing industries", Journal of Development Economics, 11:307-26. 
Levinsohn, J (1993), “Testing the Imports-as-Market-Discipline Hypothesis”, Journal of International Economics, 35:1-22.

Michaely, M; D Papageorgiou and A M Choksi (1991), Liberalizing foreign trade Lessons of experience in the developing world, Basil Blackwell, Cambridge, MA.

Nishimizu M and J Page (1990), "Trade Policy, Market Orientation and Productivity Change in Industry", in J. de Melo and A. Sapir (eds.), Trade Theory and Economic Reform: Essays in honor of Bela Balassa, Basil Blackwell, Cambridge, MA.

Pursell G (1992), "Trade Policies in India”, in D Salvatore (ed.), National Trade Policies, Greenwood Press, New York.

Pritchett, L (1996), “Measuring outward orientation in LDCs: Can it be done?", Journal of Development Economics, 49: 307-35.

Rodrik, D (1988), "The Limits of Trade Policy Reforms in Developing Countries", Journal of Economic Perspectives, 6(1): 87-105.

----(1992), “Closing the Productivity Gap: Does Trade Liberalization really help?" in G K Helleiner (ed.), Trade Policy, Industrialization and Development, Oxford University Press, New York.

---- (1995), "Trade and Industrial Policy Reform", in J Behrman and T.N. Srinivasan (eds.), Handbook of Development Economics, Volume III, North Holland, Amsterdam.

Romer, P M (1987), "Growth based on increasing returns due to specialisation", American Economic Review, 77(2): 56-62. 
Srivastava, V (1996), Liberalization, Productivity and Competition: A Panel Study of Indian Manufacturing, Oxford University Press, New Delhi.

Tybout, J (1992), "Linking Trade and Productivity: New Research Directions", The World Bank Research Observer, 6(1): 189-211.

United Nations (1987), Inrternational Comparision Project, New York.

Vousden, N (1993), "Variable specific factors and the X-efficiency cost of protection", Review of International Economics, 1(3): 234-42.

The World Bank (1989), India: An Industrializing Economy in Transition, The World Bank, Washington D.C. 